Jana Pitekova,

Ph.D., Associate professor, Catholic University in Ruzomberok, Slovakia

Maria Vrablikova,

Catholic University in Ruzomberok, Slovakia

\title{
BENCHMARKING OF SLOVAK REGIONS IN TERMS OF START-UP IMPLEMENTATION INDICATORS AND CREATIVE POTENTIAL INDICATORS
}

\begin{abstract}
Creative regions contribute to a higher standard of living, are attractive to start-ups, create new jobs, reduce brain drain and attract applicants for university education. The paper aims to compare selected indicators of implementation of start-ups and creative potential in the regions of Slovakia at NUTS 3 level and to quantify their mutual relationship. Benchmarking of 8 Slovak NUTS 3 level regions is based on 2 comparisons, namely: 6 indicators of start-ups implementation (frequency of start-ups, creation of radical innovations, employment in fast-growing companies, venture capital awareness, crowdfunding awareness and possibilities of counselling in the implementation of start-ups) and 6 indicators of creative potential (openness and diversity, human capital, cultural environment, technologies, institutional environment and creative outputs). Numerical values of these indicators are obtained from secondary research studies - e. g. modified Slovak Creative Index, Regional Innovation Scoreboard, Slovak Start-up Report and websites of innovation incubators and crowdfunding platforms. To obtain the true values of these criteria, the analysis of secondary data - desk research and the method of pairwise comparison with 91 respondents (students of Slovak universities of economic orientation with Slovak or Ukrainian nationality) was used to determine the real significance (weights) of the criteria. According to pairwise comparison, the most important indicator of start-up implementation is possibilities of counselling and the most important indicator of creative potential is creative outputs. Consequently, the relationship between the two comparisons is quantified. The global benchmark based on the implementation of start-ups is the Bratislava region, as well as in the case with creative potential. There is a strong correlation ( $85.5 \%$ ) between the scores of the compared regions. The final ranking of the 5 regions out of 8 in both comparisons is also the same. The theoretical contribution is extending of the issue of benchmarking from traditional understanding (products, services, processes) to spatial understanding (region). The main practical contribution of the paper is to identify the weaknesses of each of the compared regions through benchmarking. Its implementation can be the basis for the development of regional strategies and the introduction of new study programs at universities.

Keywords: benchmarking, creative potential, region, Slovak Republic, Start-UP.
\end{abstract}

Introduction. In the era of globalization, the emphasis is no longer placed on mass production and quantity, but on providing new value to an increasingly demanding customer and quality. The changes in the demand side and the increase in the importance of the tertiary sector (services) required the introduction of higher-order innovations based on a high level of entrepreneurial creativity and high added value. In Slovakia, so-called start-ups, which are increasingly financed by alternative sources of funding (e.g. crowdfunding) or by a combination of multiple sources due to the high initial risk, are very popular. Besides, it is now possible to evaluate the parameters of creativity and innovation from the areal point of view, respectively on a regional level. Implementation and innovative benefits of start-ups, entrepreneurial awareness of their financing and indicators of creative potential can predicate not only of the attractiveness of the region for business but also of the overall standard of living.

The position of individual regions of Slovakia in terms of implementation of start-ups and creative potential can be evaluated verbally, descriptively, respectively intuitively, but it is also necessary to know the exact differences between the regions under comparison and also to specify the areas where the individual regions are in excellent position and where there are reserves. One of the currently used quantitative comparative methods in various areas of the economy is benchmarking. It can be used, for example, to compare the performance of enterprise employees, mutual funds and other financial instruments, processes, business strategies, products, but also regions, as the region can also be seen

Cite as: Pitekova, J., Vrablikova, M. (2019). Benchmarking of Slovak Regions in Terms of Start-UP Implementation Indicators and Creative Potential Indicators. Marketing and Management of Innovations, 4, 50-68. http://doi.org/10.21272/mmi.2019.4-05 
as a product from the marketing point of view (attractiveness for tourism, attractiveness for business, good place for life, regional labour market, etc.).

The purpose of benchmarking is to get inspired by the best competitor («best practices») within the compared subjects, but it does not mean to imitate them. This is confirmed by one of the definitions of benchmarking by R. C. Camp as «seeking best practices in business that lead to excellent results». Benchmarking can also be included as a tool for systematic and proactive problem-solving in an organization or other subjects, as it aims to identify and analyse the causes of our weaknesses (Bartley et al., 2007; Gunasekaran and White, 2009; Kosturiak, 2010; Kiselakova and Sofrankova, 2014; Omoregie 2019). Omoregie (2019) further distinguishes the basic types of benchmarking: object-oriented (exploring and comparing selected product, processes, regional parameters), range-oriented (internal benchmarking, industrial benchmarking and best in class benchmarking) and the one oriented at specified business objectives and their fulfilment.

Literature Review. There is currently no precise definition of a start-up. For example, the entrepreneur from Silicon Valley Blank (2010) defines a start-up as an «organization looking for a repeatable and scalable business model». Klempova (2014), Janakova (2015) and Opait, Damian and Capatina (2019) see the main features of start-ups in scalability (flexibility, testing concepts by the needs of the target segment and the consequent possibility of modification), high growth potential, high demands on creative human capital, high risk (either succeed or not), a wide range of funding options and considers innovation potential to be the main feature. Thus, innovation is a major factor in the difference between start-ups and ordinary starting business.

VIcek (2010) also specifies these innovations and compares the start-ups to the implementation of innovations of the higher ranks of the 9-degree Valenta's innovation spectrum, where the first 3 rows represent rationalization innovations (mainly process and organizational), while the middle 3 ranks are linked to incremental innovations (e.g. a new variant of an existing product) and the last 3 rows represent radical (breakthrough) innovations, respectively new species, new genus, new strain (hybrid products such as smartphones, innovations in biotechnology and genetics, introduction of production line manufacturing, creation of the internet, etc.).

It is mainly about product innovations and can be the cause of economic cycles from a macroeconomic perspective. Crnogaj et al. (2015) found that start-ups and innovation-based businesses contribute more significantly to economic growth and the competitiveness of the economy as traditionally emerging businesses with lower levels of innovation.

Start-ups can be divided according to different criteria. For example, according to Blank (2010), Havier and Vrtikova (2016) we know:

- small-business start-up - the smallest businesses of the family type, funded in traditional ways, do not excel in breakthrough innovations,

- scalable start-up - enterprises with a vision of high growth in global conditions, are most attractive to investors because of the need for high capital,

- social start-up - business conditions are similar to scalable start-ups, but the main goal is not to make a profit, but that does not mean that it cannot make it,

- lifestyle start-up - the goal is primarily to fulfil and self-realization of the founder, based on his lifestyle, profit is not primary, is less attractive to investors,

- large-company start-up - is a very widespread kind, not setting up a new business, but the development of a new innovative product to revive a large already existing company or to penetrate new markets,

- buyable start-up - funded by venture capital or business angels if the enterprise does not have sufficient resources, is sold to a large company in the form of an acquisition or merger. 

Potential Indicators

The Slovak business environment for start-ups is, according to Janakova (2015) and the KPMG study (2016) supported by many Slovak ministries (of finance, of economics, of education, R\&D and sports) and agencies (SBA - Slovak Business Agency, SIEA - Slovak Innovation and Energy Agency, CVTI Scientific and Technical Information Centre, venture capital companies such as Neulogy Ventures, business angels and crowdfunding platforms.

The start-up consultancy is primarily provided by co-working facilities and business and technology incubators managed by the SBA. Above all, the following facts are seen as negatives by the authors: the lack of awareness among Slovak entrepreneurs of financial and non-financial instruments to support startups, lack of cooperation between start-up ecosystem members and entrepreneurs and research institutions and legislative barriers to entrepreneurship.

Barriers to set up start-ups are typical for several countries. For example, Miranda and Borges (2019) focus on researching technological incubators in Brazil and found that their members do not follow a strict hierarchical structure, but there is still insufficient support for information sharing and exchange of experience and consider the lack of communication skills of these members as a major problem. KPMG study (2016), Slavik (2018) and Ferasso et al. (2018) lists the 4 types of relationships that should operate in a start-up ecosystem: relationships between entrepreneurs and mutual learning, relationships between entrepreneurs and support organizations coordinating business activities, relationships between entrepreneurs and organizations dealing with consultancy services, mentoring and financing and relationships between entrepreneurs and other organizations (e.g. organizers of business events, fairs, exhibitions, etc.) Among the well-known Slovak start-ups, we can certainly include the world-known company ESET, Sygic navigation systems, mobile eco-houses ECOCAPSULE or Aeromobil.

Lesakova et al. (2017) examined in her study the order of factors that determine innovation activities in Slovak SMEs, which, according to their innovation activities, were divided into 3 groups: innovation leaders, innovation followers and non-innovative SMEs).

The order was as follows: financial resources, human resources, technology, state support system, innovation management and cooperation with external entities. Also, businesses assessed the barriers to introducing innovation and the order was as follows: bureaucracy, corruption, lack of state support, high costs, lack of internal financial resources, difficulty in obtaining external financial resources, lack of skilled workforce, lack of research and development knowledge, weak will to innovate, absence of innovation strategy and lack of cooperation with external entities. The ranking of factors was not statistically significantly different among the groups of innovators.

To date, a comprehensive study has not been conducted in Slovakia to address regional differences in start-ups, whether, for example, the nature of start-ups, ways of financing them in NUTS 2 or NUTS 3 regions are different or not. Therefore, if we want to evaluate the implementation of start-ups based on secondary research, we must base them on their main attributes, which are assessed annually at NUTS 2 level in the form of Regional Innovation Scoreboard (RIS).

The evaluation is based on the Innovation Scoreboard of the European Innovation Scoreboard (EIS). Innovations are classified according to OSLO Manual (product, process, marketing, organizational) and EU countries are divided due to their innovation performance in a similar way as in Lesakova et al. (2017) to the best innovators (e.g. Germany, Sweden), the following innovators (e.g. France, Austria), moderate innovators (e.g. SR, Czech Republic) and the weakest innovators (e.g. Romania, Bulgaria). The Regional Innovation Scoreboard (RIS) evaluates the EU regions at NUTS 2 level (in the case of the SR, they are west, central and east Slovakia and Bratislava region) (Fila and Kucera, 2015; Knoskova and Dudekova, 2015).

The areas and indicators of the European Innovation Scoreboard's innovation performance assessment can be found in Table 1 . 
J. Pitekova, M. Vrablikova. Benchmarking of Slovak Regions in Terms of Start-UP Implementation Indicators and Creative Potential Indicators

Table 1. Areas and indicators of EIS and RIS evaluation

\begin{tabular}{|c|c|c|}
\hline \multirow{3}{*}{$\begin{array}{l}\text { Promoting } \\
\text { innovation }\end{array}$} & $\begin{array}{l}\text { Human resource } \\
\text { Innovators }\end{array}$ & $\begin{array}{l}\text { new doctoral graduates } \\
\text { people with university education from } 30 \text { to } 34 \mathrm{y} \text {. } \\
\text { people with completed secondary education from } 20 \text { to } 24 \mathrm{y}\end{array}$ \\
\hline & $\begin{array}{l}\text { Open, excellent, attractive } \\
\text { research }\end{array}$ & $\begin{array}{l}\text { common international scientific publications } \\
10 \% \text { most cited scientific publications } \\
\text { non-EU PhD students }\end{array}$ \\
\hline & Financial support & $\begin{array}{l}\text { public R\&D expenditure } \\
\text { venture capital }\end{array}$ \\
\hline \multirow{3}{*}{$\begin{array}{l}\text { Innovation } \\
\text { activities }\end{array}$} & Business investments & \begin{tabular}{|l} 
enterprise spending on $R \& D$ \\
expenditure on innovation which does not come from $R \& D$
\end{tabular} \\
\hline & $\begin{array}{l}\text { Relationships and } \\
\text { Entrepreneurship }\end{array}$ & $\begin{array}{l}\text { internal SME Innovation } \\
\text { SMEs innovation in collaboration } \\
\text { joint public and private sector publications }\end{array}$ \\
\hline & $\begin{array}{l}\text { Industrial property rights } \\
\text { assets }\end{array}$ & $\begin{array}{l}\text { international patent applications } \\
\text { international patent applications for societal challenges } \\
\text { Community trademarks } \\
\text { Community designs }\end{array}$ \\
\hline \multirow[b]{2}{*}{$\begin{array}{l}\text { Innovation } \\
\text { outputs }\end{array}$} & Innovators & $\begin{array}{l}\text { SMEs with product or process innovation } \\
\text { SMEs with marketing or organizational innovations } \\
\text { employment in fast-growing firms in innovative industries }\end{array}$ \\
\hline & Economic effects & $\begin{array}{l}\text { employment in knowledge-intensive activities } \\
\text { export of medium and high technology products } \\
\text { export of knowledge-based services } \\
\text { selling innovations for the market and the company } \\
\text { income from licenses and patents from abroad }\end{array}$ \\
\hline
\end{tabular}

Source: own processing by Knoskova and Dudekova (2015), RIS (2017).

Another assessment offers the Global Competitiveness Index (GCI), which WEF (World Economic Forum) evaluates annually for the competitiveness of national economies. The index consists of 12 pillars: the quality of public institutions (1), infrastructure (2), macroeconomic environment (3), health and primary education (4), higher education and training (5), efficiency of the goods market (6), efficiency of labour market (7), financial market maturity (8), technological preparedness (9), market size (10), production of new products through sophisticated processes (11) and innovation (12) (GCl, 2017; Bacik et al., 2019). Sofrankova, Kiselakova and Cabinova (2017) state in their research that 7 pillars correlate significantly with the overall GCl of Slovakia, namely: 1, 2, 3, 6, 8, 11 and 12. The authors also found the average score of these pillars in 2006-2016 and placed in the first 3 ranks: the 4th, 3rd and 8th pillars and the highest reserves in the 12th, 1st and 10th pillars. In 2018, Slovakia reached the 41st place out of 140 countries evaluated, and in 2017 it was 59th place.

Lesakova et al. (2017) research show that financial resources are the most important factor for innovation activity for Slovak SMEs and their lack is a major barrier to innovation. To remove these barriers, it is appropriate to combine sources of funding. The results of the Slovak Start-up Report (2016) show that $72 \%$ of Slovak start-ups used traditional financing from their resources, $15 \%$ used the so-called $3 \mathrm{~F}$ (fools, family, friends) and $13 \%$ bank loans. Among the alternative sources of funding were mainly business angels ( $19 \%$ local, $11 \%$ foreign), venture capital ( $15 \%$ local, $9 \%$ foreign) and $11 \%$ crowdfunding. Public support was also used for $21 \%$ of start-ups (e.g. SBA, Euro-funds, Horizon 2020, Erasmus for Young Entrepreneurs), scientific grants for $9 \%$ of start-ups and services of a strategic investor in $9 \%$ of start-ups. Among alternative sources of funding, we will be more concerned with venture capital and crowdfunding. 

Potential Indicators

According to the European Venture Capital Association (EVCA), venture capital represents an investment in an enterprise at its most hazardous stage, especially at its formation. Usually, capital is provided for a medium to the long-time period (e.g. 5-7 years) and it cannot be a company that is listed on a financial market. The most well-known administrator of venture capital funds is Neulogy Ventures, which administers these funds in the Luxembourg financial market and invests primarily in start-ups in IT, energy and medical diagnostics. We can divide venture capital into five types in terms of the business life cycle:

- seed capital - is the riskiest form, start-up capital when a start-up business does not have proven results yet, investors, therefore, require a high rate of return (80-100\%);

- start-up capital - capital for starting a company into the company that already exists for a short time, the risk is lower than for seed capital, the expected return on investment is $40-70 \%$;

- another early stage - financing the initial development of a company, where target customers already exist, but it is necessary to reduce costs and improve its market position using marketing tools, $30 \%$ expected return;

- development expansion - financing the further development of the company, the risk is the lowest and is, therefore, the most attractive for investors (more than $50 \%$ ), the expected return is $25 \%$;

- turnaround capital - investing in a troubled company where a fundamental change is necessary (new product, production, management, market), the risk is high (similar to seed) (Vogl, 2015; Zimermanova in Markova et al., 2015).

Crowdfunding is a phenomenon of financing start-ups for only a few years but has a rich history, e.g. funding the building of the Statue of Liberty (publishing a call in the newspaper by editor Joseph Pulitzer) or supporting low-income families in the US in the 18th century. Currently, in the form of online crowdfunding platforms, it is of interest for approximately 10 years and its importance in investing in startups and other projects (building, artistic, social, etc.) is growing (2008 - platform Indiegogo and 2009 platform Kickstarter) (Soltes and Stofa, 2016; Herve and Schwienbacher, 2018). Herve and Schwienbacher (2018) distinguish between crowdfunding and crowdsourcing. According to them, crowdfunding is a mixture of crowdsourcing and microfinance. Based on literature (Soltes and Stofa, 2016; Dibrova, 2017; Herve and Schwienbacher, 2018) we know the following types of crowdfunding:

- donation-based crowdfunding - the gift is a principle; it is a non-repayable type of investment mainly for charity and social purposes; the reward is a good feeling;

- reward crowdfunding - the contributor receives a bonus in the form of a bonus product for the contribution, and sometimes the amount of the contribution is conditional on receiving the reward;

- presale crowdfunding - the principle is pre-sale, it is used mainly for start-ups that want to produce something, the price of a product that contributors can order is set in advance, in case of project success, the product is given them preferentially, possibly with added value, in case of failure, the money is returned to them; profits;

- profit-sharing crowdfunding - the principle is the promise of a contributor to gain a share in future

- lend/peer2peer crowdfunding - is a combination of credit, risky investment and crowdfunding, while the conditions are favourable for both partners because the crowdfunding operator has fewer fees than the bank or non-bank lending institution, the advantage is the diversification of the risk, since it concerns smaller loans in larger amounts;

- equity crowdfunding - the principle is securities, it is the least used form of crowdfunding due to administrative and legislative demands, the contributor becomes a shareholder, acquires a stake in the company's capital in the form of securities, but in case of failure, contributors may lose their contribution.

The first Slovak crowdfunding platform, which focused on art projects, was Marmelada, which is currently inactive. The most famous crowdfunding platform specializing in social and charity projects is 

Potential Indicators

www.ludialudom.sk, and in cooperation with the SPP Foundation (http://sppolocne.ludialudom.sk/onas/ciel/), it concerns public benefit projects. The Crowdberry platform (https://www.crowdberry.eu/) under the auspices of Tatra Banka, where the investor's minimum deposit is $€ 10,000$, is used for extensive investments (e.g. Ecocapsule) in the form of equity crowdfunding. The Crowdfunding platform StartLab (www.startlab.sk) is focused on start-ups, art and projects of general interest, based on a reward, while the target amount is determined by the project sponsor.

The Czech platforms Starter (www.startovac.cz) and HitHit (www.hithit.com) are also relatively used by Slovak entrepreneurs to support start-ups and creative outputs with the possibility of rewards. Various types of projects (gift or reward) are offered by the Czech Penezdroj platform (www.penezdroj.cz). Among the world-famous platforms, there is the possibility to use Indiegogo (www.indiegogo.com), a branch of the Austrian platform Conda Crowdinvesting Slovakia (https://www.conda.sk/sk/home-slovakia/), the Finnest platform, which focuses on the financing of established companies in the form of loans (https://www.finnest.com/sk) and the principle peer2peer e.g. also the Zlty melon platform is based (https://www.zltymelon.sk/) (Zelenakova, 2017).

A pioneer in the scientific exploration of creativity, which is the cornerstone of innovation and startups, is John Paul Guilford. From a psychological point of view, divergent thinking is behind creativity, allowing a person to look at the problem from different points of view, while convergent thinking seeks one right answer. Creativity is the starting point of every innovation, but its implementation depends mainly on the entrepreneur's financial capacity (Araya and Peters, 2010; Suwala, 2012). According to the Czech psychologist Frankova (2011), creativity is associated with identifying the problem and generating ideas (predominance of divergent thinking), and innovation is associated with implementation and commercial exploitation (the predominance of convergent thinking). There is a lot of definitions of creativity in the literature.

For example, according to Ullrich (Mikulastik 2010, p. 19), creativity is «the ability to get to know objects in new relationships and in an original way, to use them in a meaningful way, to see new problems where they seem not to exist, to deviate from habitual patterns of thinking and not to consider anything as steady». Florida (2002) distinguishes 3 types of creativity, namely: technological, economic (or entrepreneurial) and artistic-cultural. Classification UNCTAD (2010), in turn, distinguishes artistic creativity (dissemination of original ideas in the form of sound, text, image), scientific creativity (curiosity, desire to experiment) and economic creativity (business ideas), while considering technological creativity as part of each. At present, Creative Problem Solving (CPS) is often used at enterprise level, respectively «Out of the box thinking» represented by various methods such as e.g. brainstorming (Alex Osoborne), 6 thinking hats, which also requires a change in the organizational structures of companies, mainly in the form of decentralization and greater freedom in the workplace (Dhir, 2016). According to the research of Ritter and Mostert (2018) aren't generated ideas by 4 well-known brainstorming methods (Silence, Evolution, Random Connections and SCAMPER) significantly different and very beneficial for quality and originality of ideas is generating of ideas in groups. Support for micro-level creativity also has a significant impact on the national economy.

The first author to deal with the impact of creativity on economic development was the AustrianAmerican economist and sociologist Joseph Alois Schumpeter, who was also the author of the concept of «innovation». Regarding start-ups, we can only mention that the first introduction of a product to the market, which gave the trader a competitive advantage and a temporary monopoly, was considered to be an innovation, and he considered the other producers to be imitators. Schumpeter refers to the realization of innovations as «creative destruction», which accelerates the direction towards a new socio-economic structure of the existing society or is the cause of economic cycles (Schumpeter 1912). This economist has also developed the first classification of innovations (new products, new markets, new production methods, new sources of raw materials, new production organization), from which results the most well- 
known current classification of innovations used for example in the statistical evaluation of the innovation of enterprises, countries and regions - OSLO Manual (product, process, marketing and organizational innovations) (Cichovsky et al., 2012). Denning et al. (2014) also supports Schumpeter's idea and claims that all successful companies that have the potential to create new markets are temporary monopolies. The importance of creativity, thanks to its influence on the national economy, also penetrates the theory of regional development.

Act no. 503/2001 on the promotion of regional development defines the region as «a territorially defined area for the creation and implementation of regional and structural policies at level 2 and 3 according to the Nomenclature des unites territoriales statistiques». There are currently 8 higher territorial units (NUTS 3) in Slovakia, 4 regions by former division (NUTS 2 - BSK, west, central and east Slovakia) 79 districts (LAU 1), 138 towns and 2753 municipalities (LAU 2) (Ivanicka et al., 2014).

The author of the concept of the creative economy is John Howkins. UNCTAD $(2010$, p.10) defines the creative economy as «an evolving concept based on creative assets potentially generating economic growth and development». Vesela and Klimova (2014) and Florida (2002) believe that the creative economy is the trend following a knowledge-based economy based on information and know-how and that creativity fulfils both input and output. Purnomo and Kristiansen (2018) state, that the creative industry (it can be rational or intuitive) is incompatible with a neoclassical economic theory based on preference rationality, profit maximisation and equal access to information among actors because customer utility, in this case, is composed of economic, as well as aesthetic, spiritual, social, historical, symbolic and authenticity values, then all these will affect customers' willingness to pay.

The best-known creative economy writer is Richard Florida (2002), who is also the author of the creative class (or creative workforce). The creative class is made up of two groups of workers: supercreative core (scientists, engineers, university professors, poets, writers, architects ...) and creative professionals (employees with knowledge of high-tech health service, financial services, management ...). According to many authors, the concept of a creative economy is a continuation of the concept of a knowledge-based economy where innovation, IT and communication and digital education are at the forefront (Florida, 2002; Khanmirzaee et al., 2018).

The creative economy is part of the creative economy concept, which is impossible to identify as a primary, secondary or tertiary sector of the national economy (Kloudova, 2009). Approaches to the division of creative industries are also different. Howkins (2001) divides the creative industry into 4 intellectual property groups: Copyright Industries, Patent Industries, Trademark Industries, and Design Industries.

Another approach is presented by Throsby (2001), whose division of the creative industry is shown in concentric circles. The core is creativity-based art (Core creative arts such as music, literature, art and drama), followed by other cultural industries such as libraries, museums, and wider cultural industries, e.g. video games, computer games, TV, radio). External circle contains related industries - e.g. advertising industry, architecture, fashion design).

Creative and innovative businesses in a region work together to create a creative cluster. The term «creative cluster» refers to «the geographical concentration of the creative industry (which includes, for example, crafts, film, music, publishing, interactive software, design, etc.) that collects all resources to optimize the creation, production, dissemination and use of creative work» (Ali Taha, Tej 2015, p. 28). Although clusters are characterized by the co-operation of different stakeholders, it is a growing trend for clusters to accept ideas from outside the cluster - the so-called open innovation that can also improve their overall innovation potential (Park et al., 2012; Marcolin et al., 2017; Tyukhtenko et al., 2019).

Another important concept in the field of the creative economy is the creative city, respectively a city supporting talented workers and innovation, especially start-up business. According to Fitrinitia et al. (2018), such a city should meet 5 conditions, namely: networking of businesses and exchange of experience, mentoring, regular verification of new ideas, support for infrastructure (resp. start-up 

Potential Indicators

ecosystem, innovation incubators) and support for investment in start-ups, respectively making funding opportunities more transparent. Borsekova et al. (2015) consider not only the highly developed metropolises, where young and innovative workforce prevails but also the rural environment, nostalgic elements and cultural heritage (e.g. UNESCO - listed folk architecture, cultural events in the historical spirit, etc.) as part of the region's creative potential. There are different approaches to how the creative potential of countries and regions can be measured.

The best-known way of measuring the creative economy by Florida (2002) is a 3T index which consists of talent index, technology index, and tolerance index. Modified 3T Index for European conditions, socalled The Euro-Creativity Index was developed by Florida and Tinagli in 2004. Table 2 provides a comparison of the indices. Due to the availability of data, many modifications have been made to the EuroCreativity Index adapted to national and regional conditions.

Table 2. Comparison of 3T Index (Left) and Euro-Creativity Index (Right)

\begin{tabular}{|c|c|c|c|}
\hline Talent Index & & Euro-Talent Index & \\
\hline Human capital index & $\begin{array}{c}\% \text { of the population with } \\
\text { a university degree }\end{array}$ & Human capital index & $\begin{array}{c}\% \text { of the population aged } 25-64 \\
\text { y. with university degree }\end{array}$ \\
\hline \multirow[t]{2}{*}{ Creative class index } & $\begin{array}{l}\text { creative class } \\
\text { concentration }\end{array}$ & Creative class index & the rate of creative employment \\
\hline & & Scientific talent index & $\begin{array}{l}\text { the number of researchers and } \\
\text { engineers per } 1,000 \text { workers }\end{array}$ \\
\hline Technology Index & & Euro-Technology Index & \\
\hline Innovation Index & $\begin{array}{c}\text { number of patents per } \\
\text { person }\end{array}$ & Innovation index & $\begin{array}{c}\text { the number of patents per } 1 \text { mil. } \\
\text { residents }\end{array}$ \\
\hline High-tech index & $\begin{array}{c}\% \text { of the output of high- } \\
\text { tech industries on overall } \\
\text { output }\end{array}$ & High-tech index & $\begin{array}{l}\text { the number of high-tech patents } \\
\text { to } 1 \text { million residents }\end{array}$ \\
\hline & & R\&D index & $\%$ R\&D to GDP \\
\hline Tolerance Index & & Euro-Tolerance Index & \\
\hline Gay index & $\begin{array}{l}\text { The number of gays in } \\
\text { the region in the total } \\
\text { population of the region }\end{array}$ & Index of approaches & $\begin{array}{l}\% \text { of tolerant people towards } \\
\text { minorities }\end{array}$ \\
\hline Bohemian index & $\begin{array}{l}\text { Population with an } \\
\text { artistic focus in the } \\
\text { region }\end{array}$ & Index of values & $\begin{array}{l}\text { a reflection of traditions in the } \\
\text { values of the population }\end{array}$ \\
\hline Immigration Index & $\begin{array}{l}\% \text { of immigrants in the } \\
\text { region }\end{array}$ & Self-expression index & $\begin{array}{l}\text { attitude towards individual rights } \\
\text { and expression }\end{array}$ \\
\hline
\end{tabular}

Source: own processing by Florida (2002), Florida and Tinagli (2004), Kloudova (2009).

White et al. (2014) also see negatives in the indicators of measuring the creative economy. Although these indicators are based on available research, they are not empirically tested, but national and regional strategies and policies in this area can be formed. It is precisely due to the data availability and cultural differences between countries and regions that creative indexes need to be modified to national and regional conditions. In the case of the Slovak Republic, it is the Slovak Creative Index (SCI) based on ECI and involving 6 evaluation criteria, which are presented by the study of the company Neulogy (2014) and Hudec and Klasova (2016). In both studies, statistical data from the Statistical Office of the SR, from ministries, from the Industrial Property Office and the results of the European Social Survey (2004) were used to determine these 6 criteria (sub-indices).

In the sub-index Openness and Diversity, for example, the attitude of the population towards national and sexual minorities, the share of foreigners in cultural activities (exhibitions, performances) or the share 

Potential Indicators

of foreigners in employment were evaluated. In the sub-index Human Capital, for example, the proportion of art education institutions, the number of doctoral students and the number of workers with an artistic profession were evaluated. In the sub-index Cultural environment, for example, household spending on culture and abundance of different cultural institutions (e.g. theatres, cinemas, libraries, galleries) were evaluated. In the Technologies sub-index, households with internet access and R\&D expenditure were evaluated. In the sub-index, the Institutional Environment was evaluated e.g. state financial support for culture and intellectual property protection parameters. In the sub-index Creative outputs were evaluated e.g. economic effects of creativity (share of creative industry on GDP, book, music and film outputs), publications and designs. The Neulogy study (2014) used Z-score standardization and a new study by Hudec and Klasova (2016) used an analysis of the main components (PCA) to analyse 8 self-governing regions (NUTS 3). Both studies with the help of these calculations can divide the regions to above average $(\mathrm{SCl}>0)$ and below-average $(\mathrm{SCl}<0)$ creative, it is also possible to proceed in the same way in the evaluation of sub-indices and identify which region in which sub-index is above-average or below-average evaluated. Kloudova and Chwaszcz (2014) explored how creative industries are influencing selected macroeconomic indicators of the Czech Republic, which is the closest to the Slovak Republic from cultural and historical points of view. Based on CZ- NACE they identified creative industries as J - Information and Communication and $\mathrm{M}$ - Professional, Scientific and Technical Activities. They found that production and exports of these industries increased significantly between 1990 and 2010 and that the share of those employed in the creative industries increased compared to total employment in the national economy. In testing the second hypothesis, a strong dependence between the existence of creative industries and selected macroeconomic indicators (GDP, labour supply and average income) was confirmed. Another important indicator of economic growth and the country's living standards is labour productivity, which is also influenced by creativity and innovation. This is also confirmed by Carnicky et al. (2017), examining the productivity of V4 countries that have been EU members since 2004, according to data from 2000, 2008 and 2015. Although all countries are characterized by low labour productivity, the annual change expressed by GVA (Gross Value Added) between these years is increasing and is higher than in the developed countries of Western Europe. In the case of the Slovak Republic, this is a shift from the 8th lowest labour productivity in the EU (in 2000) to 12th place (in 2015), which is the most significant change among V4 countries.

Methodology and research methods. According to NUTS 2 level, regions in Slovakia are as follows: Bratislava region (BA), Western Slovakia (WS), Central Slovakia (CS) and Eastern Slovakia (ES). Lower NUTS 3 regions (or self-governing regions) are named in the Slovak Republic according to the largest towns where the municipalities are located and are as follows (for better geographical clarity we also mention their inclusion in NUTS 2): BA - Bratislava region (BA), BB - Banska Bystrica region (CS), KE Kosice region (ES), NR - Nitra region (WS), PO - Presov region (ES), TN - Trencin region (WS), TTTrnava region (WS) and ZA- Zilina region (CS). The paper aims to compare selected indicators of implementation of start-ups and creative potential in the regions of Slovakia at NUTS 3 level and to quantify their mutual relationship. Based on this goal, we formulate 3 research questions:

RQ1: Which NUTS 3 region of Slovakia is a global benchmark in the area of selected indicators of start-ups implementation?

RQ2: Which NUTS 3 region of Slovakia is a global benchmark in the area of creative potential indicators?

$\mathrm{RQ3}$ : What is the relationship between benchmarking comparison of Slovakia regions at NUTS 3 level in terms of indicators of implementation of start-ups and in terms of indicators of creative potential?

To answer the research questions RQ1 and RQ2, we used the benchmarking methodology that we adopted from the product benchmarking methodology (Kovalova and Nogova, 2016; Vrablikova and 
Loucanova, 2017; Omoregie 2019), which is used to find the bottlenecks of the compared products and then to identify innovative product intentions. It consists of the following steps:

1) selection of criteria for evaluating the implementation of start-ups and creative potential for NUTS 3 regions, analysing the values of individual criteria (based on secondary so-called desk data);

2) in solving RQ1, the selection of criteria that correspond to the implementation of start-ups (based on theoretical definitions); the starting point is selected indicators of Slovak Start-up Report (2016), RIS (2017) and data from crowdfunding platforms and consulting organizations;

3) in the RQ2 solution, we consider $6 \mathrm{SCl}$ sub-indices according to Hudec and Klasova (2016) as evaluation criteria;

4) determination of criteria significance using a paired comparison realized through a questionnaire survey (91 respondents - students of Slovak universities of economics - future managers or entrepreneurs - 40 Slovak students and 51 Ukrainian students), while the real significance (w) or the importance of criteria will be determined as follows:

a) mean significance: $\varnothing \mathrm{vi}=100 /$ number of criteria,

b) significance coefficient: $k i$ = frequency of occurrence (based on pairwise comparison),

c) average significance coefficient: $\varnothing \mathrm{ki}=\Sigma \mathrm{ki} /$ number of criteria,

d) conversion using deviation: CUD $=(\mathrm{ki}-\varnothing \mathrm{ki})^{*} \mathrm{~d}$,

e) deviation: $\mathrm{d}=\Sigma \mathrm{vi} / \Sigma \mathrm{ki}$,

f) real significance (weights): $w=\varnothing v$ i + CUD;

5) the final stage of benchmarking is the best value method based on knowledge of the real values of criteria of the benchmarking of regions and the real significance (w), which is the result of previous benchmarking steps. The tendency $(t)$ of the criterion can be increasing or decreasing depending on whether we want to maximize or minimize the criterion value, and to identify global benchmarks (RQ1, $\mathrm{RQ2}$ ) we proceed as follows:

a) actual criteria values $(x)$,

b) transformed values of criteria (a): if the criterion tendency is increasing: $a=$ actual value / highest value; if the tendency of the criterion is decreasing: $a=$ lowest value / actual value,

c) point values for individual criteria (b): $b=a{ }^{*} w$,

d) final score for a given region $(B): B=\Sigma b$;

6) the last step (response to RQ3) is to quantify the correlation between benchmarking results of NUTS level 3 regions in terms of implementation of start-ups and, in terms of creative potential, by Pearson's (nominal) correlation coefficient.

Results. The first step is the solution of the RQ1: Benchmarking of regions of Slovakia by indicators of implementation of start-ups. To implement the benchmarking of the regions according to the indicators of the implementation of start-ups, we have chosen 6 indicators (evaluation criteria) that most closely correspond to the definitions of start-ups and the specific forms of financing. We chose the criterion of the Frequency of start-ups (I.) because the existence of other start-ups in the region may encourage other potential entrepreneurs to perform, the figures (in \%) of the criteria were drawn from the Slovak Start-up Report (2016), which we recalculated from NUTS 2 to NUTS 3 by number of population. Criterion the Creation of radical innovations (II.) given by the coefficient (the so-called normalized score) was taken from the RIS (2017). Similarly, the criteria like Employment in fast-growing companies (III.) and Venture capital awareness (IV.) respectively its use by entrepreneurs. The values of criteria II. - IV. were also recalculated to the NUTS 3 level. The values of criteria of Crowdfunding awareness (V.) were obtained from the websites of the most used crowdfunding platforms, i.e. Crowdberry, Start lab, Startovac and HitHit, where we focused on the number of ongoing and completed start-up projects, and we assigned them to their respective self-governing region according to the founder (more in Table 3). Values of the 
J. Pitekova, M. Vrablikova. Benchmarking of Slovak Regions in Terms of Start-UP Implementation Indicators and Creative Potential Indicators

criterion Possibilities of counselling in the implementation of start-ups (VI.) were obtained by identifying the number of coworking facilities and business and technology incubators in individual self-governing regions (more in Table 3). An overview of evaluation criteria, units of measure and numerical values for NUTS level 3 regions can be found in Table 4.

Table 3. Use of crowdfunding platforms in individual self-governing regions (number of ongoing and completed start-up projects), number of coworking, business and technology incubators and examples of ongoing crowdfunding start-up projects (criteria V. and VI.)

\begin{tabular}{|c|c|c|c|c|c|c|c|c|}
\hline Platform & BA & BB & KE & NR & PO & TN & TT & ZA \\
\hline Crowdberry & 6 & 0 & 0 & 0 & 1 & 0 & 1 & 0 \\
\hline Startlab & 19 & 6 & 3 & 3 & 4 & 4 & 1 & 3 \\
\hline Startovac & 4 & 1 & 0 & 0 & 0 & 0 & 0 & 0 \\
\hline HitHit & 5 & 1 & 1 & 1 & 0 & 0 & 0 & 0 \\
\hline Total (V.) & 34 & 8 & 4 & 4 & 5 & 4 & 2 & 3 \\
\hline Mechanism & BA & BB & KE & NR & PO & TN & TT & ZA \\
\hline Coworking & 11 & 2 & 2 & 2 & 2 & 1 & 1 & 3 \\
\hline $\mathrm{Bl} / \mathrm{TI}$ & 3 & 2 & 5 & 1 & 1 & 1 & 1 & 2 \\
\hline Total (VI.) & 14 & 4 & 7 & 3 & 3 & 2 & 2 & 5 \\
\hline
\end{tabular}

Examples of projects on individual crowdfunding platforms: Crowdberry - Ecocapsule/Mobile eco-houses

(BA), Maly gazda/Small farmer (PO), Herbet syrupy/Herbet syrups (TT), Startlab - Slovenska prirodna dekorativna kozmetika/Slovak natural decorative cosmetics (BB), Do vrecuska/ To the sachet (PO), Startovac Cat cafe Macinezy (BA), HitHit - MODOO - creative waste solution (BA)

Source: own processing based on crowdfunding platforms, consulting organizations and coworking websites.

Table 4. Overview of evaluation criteria, units of measure and values for NUTS 3 regions

\begin{tabular}{|c|c|c|c|c|c|c|c|c|c|}
\hline Crit. & u. m. & BA & BB & KE & NR & PO & TN & TT & ZA \\
\hline I. & $\%$ & 0,750 & 0,049 & 0,049 & 0,019 & 0,051 & 0,016 & 0,015 & 0,051 \\
\hline II. & coef. & 0,376 & 0,147 & 0,184 & 0,077 & 0,190 & 0,066 & 0,063 & 0,155 \\
\hline III. & coef. & 0,914 & 0,263 & 0,230 & 0,260 & 0,236 & 0,225 & 0,214 & 0,278 \\
\hline IV. & coef. & 0,257 & 0,095 & 0,059 & 0,079 & 0,061 & 0,068 & 0,065 & 0,101 \\
\hline V. & quantity & 34 & 8 & 4 & 4 & 5 & 4 & 2 & 3 \\
\hline VI. & quantity & 14 & 4 & 7 & 3 & 3 & 2 & 2 & 5 \\
\hline
\end{tabular}

Source: own processing according to Slovak Startup Report (2016), RIS (2017), websites of crowdfunding platforms and consulting organizations.

In the next step, we calculated the real significance (importance/weight) of the criteria by using the benchmarking methodology, using the formulas given in the methodology. To increase objectivity, 91 paired comparisons were made in the form of a questionnaire survey (Table 5). The order of criteria according to respondents' preferences and calculated real significance (w) is as follows:

VI. - Possibilities of counselling in the implementation of start-ups (24.10);

III. - Employment in fast-growing companies (18.10);

II. - Creation of radical innovations (17.15);

V. - Crowdfunding awareness (16.19);

IV. - Venture capital awareness (12.67);

I. - Frequency of start-ups (11.79). 
Table 5. Benchmarking of regions NUTS 3 (RQ1)

Start-UP $=$ a Start-UP business whose main element is innovation and difference from the competition

Explanatory notes on the criteria for evaluating regions in terms of indicators of implementation of start-ups:

1. frequency (count) of start-ups - when other start-ups in the region can also motivate future start-up founders, e.g. in the form of cooperation between several innovative enterprises

2. creation of radical innovations - revolutionary innovations for the company and the market, a new value for the customer 3. employment in fast-growing companies - start-up has a social and economic dimension, creates jobs and can reduce brain drain from the region

4. venture capital awareness- e.g. knowledge of start-up entrepreneurs of the region about types of venture capital and about companies that provide venture capital

5. crowdfunding awareness (funding through contributions from individuals to a business plan) - e.g. region entrepreneurs' knowledge of crowdfunding and crowdfunding platforms (crowdfunding websites)

6. possibilities of counselling in the implementation of start-ups - e.g. co-working, innovation incubators, consultation with business start-up experts, legal aid, etc.

In your opinion, which of the following criteria has a greater impact on the region's attractiveness for launching startups? (always mark only «a» or «b» option)
a) frequency of start-ups
a) frequency of start-ups
b) creation of radical innovations
a) frequency of start-ups
a) frequency of start-ups
b) venture capital awareness
a) frequency of start-ups
b) crowdfunding awareness
b) possibilities of counselling
a) creation of radical innovations b) employment in fast-growing companies
$\begin{array}{ll}\text { a) creation of radical innovations } & \text { b) venture capital awareness }\end{array}$
$\begin{array}{ll}\text { a) creation of radical innovations } & \text { b) crowdfunding awareness }\end{array}$
$\begin{array}{ll}\text { a) creation of radical innovations } & \text { b) possibilities of counselling }\end{array}$
a) employment in fast-growing companies b) venture capital awareness
a) employment in fast-growing companies b) crowdfunding awareness
a) employment in fast-growing companies b) possibilities of counselling
$\begin{array}{ll}\text { a) venture capital awareness } & \text { b) crowdfunding awareness }\end{array}$
$\begin{array}{ll}\text { a) venture capital awareness } & \text { b) possibilities of counselling }\end{array}$
$\begin{array}{ll}\text { a) crowdfunding awareness } & \text { b) possibilities of counselling }\end{array}$

b) employment in fast-growing companies

Explanatory notes on criteria for evaluating regions in terms of creative potential indicators:

1. openness and diversity - e.g. the attitude of the population towards national minorities, the share of other nationals in employment

2. human capital - e.g. the proportion of educational institutions, the number of doctoral students and the number of employees with a scientific and artistic focus, student creativity

3.cultural environment - e.g. household expenditure on culture and number of different cultural institutions (theatres, cinemas, libraries, galleries, museums, cultural events - e.g. festivals)

4. technologies - e.g. the number of households with Internet access, the use of modern communication technologies, the level of computer literacy of the region's population

5. institutional environment - e.g. protection of intellectual property (patents, trademarks, ...), promotion of innovative projects by VUC, government, EU

6. creative outputs - e.g. economic effects of creativity (share of creative industry on GDP / on employment), book, music and film outputs, publications and designs (marketing agencies), innovated products and services

Which of the following criteria do you think has a greater impact on the region's creative potential?
a) openness and diversity
b) human capital
a) openness and diversity
b) cultural environment
a) openness and diversity
b) technologies
a) openness and diversity
b) institutional environment
a) openness and diversity
b) creative outputs
a) human capital
b) cultural environment 
J. Pitekova, M. Vrablikova. Benchmarking of Slovak Regions in Terms of Start-UP Implementation Indicators and Creative Potential Indicators

Continued Table 5

\begin{tabular}{ll}
\hline a) human capital & b) technologies \\
a) human capital & b) institutional environment \\
a) human capital & b) creative outputs \\
a) cultural environment & b) technologies \\
a) cultural environment & b) institutional environment \\
a) cultural environment & b) creative outputs \\
a) technologies & b) institutional environment \\
a) technologies & b) creative outputs \\
a) institutional environment & b) creative outputs
\end{tabular}

According to what other criteria (apart from the above) would you assess the region's creative and innovative potential?

What are your ideas of practice after completing a university degree in economics?

Do you plan to work or do business in Slovakia after graduating?

a) yes + reasons

b) not + reasons

What do you think is the main barrier to start-ups and innovative business in Slovakia?

How can Christianity education influence the region's creative potential?

Thank you for completing the questionnaire.

Jana Pitekova and Maria Vrablikova.

The final step in identifying the global benchmark of regions (Table 6) according to the indicators of the implementation of start-ups is to substitute real values $(x)$. Transformed values (a) were in all cases the ratio of actual value to the best one, as the trend of all indicators is increasing (we want to maximize the value of indicators). We have multiplied the transformed values by the real significance $(w)$ of the respective criterion and we have obtained the actual values of the criteria for each region (b), from where we can see which region is the local benchmark for which criterion.

Table 6. Benchmarking of regions NUTS 3 (RQ1)

\begin{tabular}{|c|c|c|c|c|c|c|c|c|}
\hline $\begin{array}{l}\text { Reg. } \\
\text { Crit. }\end{array}$ & BA & BB & KE & NR & PO & TN & TT & ZA \\
\hline \multirow{3}{*}{$\begin{array}{c}\text { I. } \\
(11,79)\end{array}$} & $x=0,750$ & $x=0,049$ & $x=0,049$ & $x=0,019$ & $x=0,051$ & $x=0,016$ & $x=0,015$ & $x=0,051$ \\
\hline & $a=1,000$ & $a=0,065$ & $a=0,066$ & $a=0,025$ & $a=0,068$ & $a=0,021$ & $a=0,020$ & $a=0,069$ \\
\hline & $b=11,790$ & $b=0,766$ & $b=0,778$ & $b=0,295$ & $b=0,802$ & $b=0,248$ & $b=0,236$ & $\mathrm{~b}=0,814$ \\
\hline \multirow{3}{*}{$\begin{array}{c}\text { II. } \\
(17,15)\end{array}$} & $x=0,376$ & $x=0,147$ & $x=0,184$ & $x=0,077$ & $x=0,190$ & $x=0,066$ & $x=0,063$ & $x=0,155$ \\
\hline & $a=1,000$ & $a=0,390$ & $a=0,490$ & $a=0,204$ & $a=0,505$ & $a=0,176$ & $a=0,168$ & $a=0,413$ \\
\hline & $b=17,150$ & $b=6,689$ & $b=8,404$ & $b=3,499$ & $b=8,661$ & $b=3,019$ & $b=2,881$ & $b=7,083$ \\
\hline \multirow{3}{*}{$\begin{array}{c}\text { III. } \\
(18,10)\end{array}$} & $x=0,914$ & $x=0,263$ & $x=0,230$ & $x=0,260$ & $x=0,236$ & $x=0,225$ & $x=0,214$ & $x=0,278$ \\
\hline & $a=1,000$ & $a=0,288$ & $a=0,251$ & $a=0,285$ & $a=0,259$ & $a=0,246$ & $a=0,234$ & $a=0,304$ \\
\hline & $b=18,100$ & $b=5,212$ & $\mathrm{~b}=4,543$ & $b=5,159$ & $b=4,688$ & $\mathrm{~b}=4,453$ & $\mathrm{~b}=4,235$ & $b=5,502$ \\
\hline \multirow{3}{*}{$\begin{array}{c}\text { IV. } \\
(12,67)\end{array}$} & $x=0,257$ & $x=0,095$ & $x=0,059$ & $x=0,079$ & $x=0,061$ & $x=0,065$ & $x=0,068$ & $x=0,101$ \\
\hline & $a=1,000$ & $a=0,370$ & $a=0,230$ & $a=0,307$ & $a=0,237$ & $a=0,265$ & $a=0,252$ & $a=0,392$ \\
\hline & $b=12,670$ & $b=4,688$ & $b=2,914$ & $b=3,890$ & $b=3,003$ & $b=3,358$ & $b=3,193$ & $b=4,967$ \\
\hline \multirow{3}{*}{$\begin{array}{c}\text { V. } \\
(16,19)\end{array}$} & $x=34$ & $x=8$ & $x=4$ & $x=4$ & $x=5$ & $x=4$ & $x=2$ & $x=3$ \\
\hline & $a=1,000$ & $a=0,235$ & $a=0,118$ & $a=0,118$ & $a=0,147$ & $a=0,118$ & $a=0,059$ & $a=0,088$ \\
\hline & $b=16,190$ & $b=3,805$ & $\mathrm{~b}=1,910$ & $b=1,910$ & $b=2,380$ & $b=1,910$ & $\mathrm{~b}=0,955$ & $b=1,425$ \\
\hline \multirow{3}{*}{$\begin{array}{c}\text { VI. } \\
(24,10)\end{array}$} & $x=14$ & $x=4$ & $x=7$ & $x=3$ & $x=3$ & $x=2$ & $x=2$ & $x=5$ \\
\hline & $a=1,000$ & $a=0,286$ & $a=0,500$ & $a=0,214$ & $a=0,214$ & $a=0,143$ & $a=0,143$ & $a=0,357$ \\
\hline & $b=24,100$ & $b=6,893$ & $b=12,050$ & $b=5,157$ & $b=5,157$ & $b=3,446$ & $b=3,446$ & $b=8,604$ \\
\hline$B=\Sigma b$ & 100,000 & 28,053 & 30,599 & 19,910 & 24,691 & 16,434 & 14,946 & 28,395 \\
\hline Order & 1. & 4. & 2. & 6. & 5. & 7. & 8. & 3. \\
\hline
\end{tabular}

Source: own processing. 
J. Pitekova, M. Vrablikova. Benchmarking of Slovak Regions in Terms of Start-UP Implementation Indicators and Creative Potential Indicators

From the resulting sum, we have identified a global benchmark, and that is the Bratislava region with the maximum score. This region is also a local benchmark in all criteria. Since Slovakia is known for its high regional differences, the score of other regions in the area of start-ups is less than $1 / 3$ of the Bratislava region. In the second place came the highly developed region of Kosice, where there is a high share of IT sector and in the third place the region of Zilina, where the automotive industry is the source of innovation. Presov region with the highest number of inhabitants ended up surprisingly in 5th place. In addition to Presov, fast-growing industrial companies in Poprad are also a source of innovation and start-ups. The last place belongs to Trnava region.

The second step is the solution of the RQ2: Benchmarking of regions of Slovakia according to indicators of creative potential. Similarly, we also evaluated the benchmarking of Slovakia's regions according to 6 indicators of creative potential (or according to SCl - Hudec, Klasova, 2016), namely: Openness and Diversity (I.), Human Capital (II.), Cultural Environment (III.), Technologies (IV.), Institutional Environment (V.) and Creative Outputs (VI.). Since the values were given by distance from average (negative numbers for sub-average regions), we transformed the values into points from 1 to 8 , where 8 points were assigned to the best-rated region and 1 point to the worst rated region under each criterion. An overview of the evaluation criteria, units of measure and numerical values for NUTS 3 regions can be found in Table 7 .

Table 7. Overview of evaluation criteria, units of measure and values for NUTS 3 regions

\begin{tabular}{|c|c|c|c|c|c|c|c|c|c|}
\hline Crit. & u.m. & BA & BB & KE & NR & PO & TN & TT & ZA \\
\hline I. & points & $1,653(8)$ & $-1,094(1)$ & $0,447(7)$ & $-0,403(3)$ & $0,353(6)$ & $-0,311(4)$ & $-0,458(2)$ & $-0,186(5)$ \\
\hline II. & points & $1,378(6)$ & $2,376(8)$ & $1,555(7)$ & $-0,550(4)$ & $-1,771(3)$ & $-2,740(1)$ & $-1,921(2)$ & $0,572(5)$ \\
\hline III. & points & $4,016(8)$ & $0,393(7)$ & $-0,379(6)$ & $-0,905(3)$ & $-1,133(1)$ & $-0,910(2)$ & $-0,651(4)$ & $-0,430(5)$ \\
\hline IV. & points & $3,148(8)$ & $-0,331(6)$ & $0,040(7)$ & $-0,578(3)$ & $-0,368(5)$ & $-0,583(2)$ & $-0,846(1)$ & $-0,482(4)$ \\
\hline V. & points & $2,249(8)$ & $-1,007(1)$ & $-0,948(3)$ & $-0,420(4)$ & $-0,993(2)$ & $0,372(6)$ & $0,268(5)$ & $0,478(7)$ \\
\hline VI. & points & $3,073(8)$ & $-0,348(3)$ & $-0,265(4)$ & $-0,100(6)$ & $-0,630(2)$ & $-0,020(7)$ & $-1,425(1)$ & $-0,254(5)$ \\
\hline
\end{tabular}

Source: Own processing by Hudec and Klasova (2016).

Analogous to the determination of the real significance of the criteria (w) for the implementation of start-ups, we also proceeded to evaluate the creative potential by pairwise comparison with 91 respondents. The order of the criteria was as follows: VI. - Creative outputs (22.71), II. - Human capital (19.19), IV. - Technologies (18.17), I. - Openness and diversity (14.14), V. - Institutional environment (13.04) and III. - Cultural environment (12.75). We also proceeded in the same way (Table 8 ) in the final benchmarking of NUTS 3 regions by creative potential indicators (actual values - transformed values local benchmarks - global benchmark).

Table 8. Benchmarking of regions NUTS 3 (RQ2)

\begin{tabular}{|c|c|c|c|c|c|c|c|c|}
\hline $\begin{array}{l}\text { Reg. } \\
\text { Crit. }\end{array}$ & BA & BB & KE & NR & PO & TN & TT & ZA \\
\hline \multirow{3}{*}{ I. $(14,14)$} & $x=8$ & $x=1$ & $x=7$ & $x=3$ & $x=6$ & $x=4$ & $x=2$ & $x=5$ \\
\hline & $a=1,000$ & $a=0,125$ & $a=0,875$ & $a=0,375$ & $a=0,750$ & $a=0,500$ & $a=0,250$ & $a=0,625$ \\
\hline & $b=14,140$ & $b=1,768$ & $b=12,373$ & $b=5,303$ & $b=10,605$ & $\mathrm{~b}=7,070$ & $b=3,535$ & $b=8,838$ \\
\hline \multirow{3}{*}{ II. $(19,19)$} & $x=6$ & $x=8$ & $x=7$ & $x=4$ & $x=3$ & $x=1$ & $x=2$ & $x=5$ \\
\hline & $a=0,750$ & $a=1,000$ & $a=0,875$ & $a=0,500$ & $a=0,375$ & $a=0,125$ & $a=0,250$ & $a=0,625$ \\
\hline & $b=14,393$ & $b=19,190$ & $\mathrm{~b}=16,791$ & $b=9,595$ & $b=7,196$ & $\mathrm{~b}=2,399$ & $b=4,798$ & $b=11,994$ \\
\hline \multirow{3}{*}{ III. $(12,75)$} & $x=8$ & $x=7$ & $x=6$ & $x=3$ & $x=1$ & $x=2$ & $x=4$ & $x=5$ \\
\hline & $a=1,000$ & $a=0,875$ & $a=0,750$ & $a=0,375$ & $a=0,125$ & $a=0,250$ & $a=0,500$ & $a=0,625$ \\
\hline & $\mathrm{b}=12,750$ & $b=11,156$ & $b=9,563$ & $b=4,781$ & $b=1,594$ & $b=3,188$ & $b=6,375$ & $b=7,969$ \\
\hline \multirow{3}{*}{ IV. $(18,17)$} & $x=8$ & $x=6$ & $x=7$ & $x=3$ & $x=5$ & $x=2$ & $x=1$ & $x=4$ \\
\hline & $a=1,000$ & $a=0,750$ & $a=0,875$ & $a=0,375$ & $a=0,625$ & $a=0,250$ & $a=0,125$ & $a=0,500$ \\
\hline & $b=18,170$ & $b=13,628$ & $b=15,899$ & $b=6,814$ & $b=11,356$ & $b=4,543$ & $b=2,271$ & $b=9,085$ \\
\hline
\end{tabular}


J. Pitekova, M. Vrablikova. Benchmarking of Slovak Regions in Terms of Start-UP Implementation Indicators and Creative Potential Indicators

\begin{tabular}{|c|c|c|c|c|c|c|c|c|}
\hline \multicolumn{9}{|c|}{ Continued Table 8} \\
\hline \multirow{3}{*}{ V. $(13,04)$} & $x=8$ & $x=1$ & $x=3$ & $x=4$ & $x=2$ & $x=6$ & $x=5$ & $x=7$ \\
\hline & $a=1,000$ & $a=0,125$ & $a=0,375$ & $a=0,500$ & $a=0,250$ & $a=0,750$ & $a=0,625$ & $a=0,875$ \\
\hline & $b=13,040$ & $\mathrm{~b}=1,630$ & $\mathrm{~b}=4,890$ & $\mathrm{~b}=6,520$ & $b=3,260$ & $b=9,780$ & $b=8,150$ & $b=11,410$ \\
\hline \multirow{3}{*}{ VI. $(22,71)$} & $x=8$ & $x=3$ & $x=4$ & $x=6$ & $x=2$ & $x=7$ & $x=1$ & $x=5$ \\
\hline & $a=1,000$ & $a=0,375$ & $a=0,500$ & $a=0,750$ & $a=0,250$ & $a=0,875$ & $a=0,125$ & $a=0,625$ \\
\hline & $\mathrm{b}=22,710$ & $\mathrm{~b}=8,516$ & $b=11,355$ & $\mathrm{~b}=17,033$ & $b=5,678$ & $\mathrm{~b}=19,871$ & $b=2,839$ & $b=14,194$ \\
\hline$B=\Sigma b$ & 95,203 & 55,888 & 70,871 & 50,046 & 39,689 & $\begin{array}{l}46,851 \\
\end{array}$ & 27,968 & 63,490 \\
\hline Order & 1. & 4. & 2. & 5. & 7. & 6. & 8. & 3. \\
\hline
\end{tabular}

Source: Own processing.

The global benchmark of the region's creative potential is the Bratislava region, which is not a local benchmark for each criterion compared to the assessment of regions according to the start-up criteria. The local benchmark for the human capital criterion is Banska Bystrica region. The ranking in the first 4 places is the same as in the evaluation of start-ups, also the last place belongs to Trnava region according to both benchmarks. The Presov region in terms of its creative potential is the last but one, i.e. in the seventh place.

The last research question RQ3: The relationship between the two benchmarking comparisons of NUTS 3 regions was to quantify the correlation between benchmarking of NUTS 3 regions in terms of indicators of implementation of start-ups and creative potential (Table 7). To quantify the dependence between nominal variables (the final score of the regions), we used Pearson's correlation coefficient, which is 0.855 , i.e. a strong dependence $(85.5 \%)$. At the same time, we can see that in the 5 regions of the Slovak Republic, the final ranking for both benchmarking comparisons is also the same (1.BA, 2.KE, 3.ZA, 4.BB and 8.TT). Exceptions are only 3 regions, namely PO ( $5^{\text {th }}$ and $7^{\text {th }}$ place), NR (6 $6^{\text {th }}$ and $5^{\text {th }}$ place) and $\operatorname{TN}\left(7^{\text {th }}\right.$ and $6^{\text {th }}$ place).

Conclusions. The paper aimed to compare selected indicators of implementation of start-ups (RQ1) and creative potential (RQ2) in regions of Slovakia at NUTS 3 level and to quantify their mutual relationship (RQ3). In the theoretical part, we described the start-ups, alternative financing options (mainly venture capital and crowdfunding) and the concept of creative economy, where we used Slovak and foreign literature, conference and journal publications indexed in Web of Science and Scopus as well as secondary research sources -Slovak scientific studies dealing with this issue (KPMG, Neulogy, Regional Innovation Scoreboard, Slovak Start-up Report). Key methods were benchmarking and desk research (secondary data analysis). The actual numerical values of the benchmarking criteria for the evaluation of the implementation of start-ups were obtained from the studies carried out, namely: Slovak Startup Report (2016), RIS (2017) and also from the crowdfunding platforms and advisory organizations, in the case of evaluating the creative potential, we used the values of the modified Slovak Creative Index (SCl) from Hudec and Klasova (2016).

As part of the RQ1 solution, we found that the global benchmark (also local in all 6 indicators) of the implementation of start-ups is the Bratislava Region, this region is also a global benchmark for the creative potential of self-governing regions (RQ2). For both benchmarking we used a pairwise comparison method to determine significance, using a questionnaire that was distributed to 91 respondents (students of Slovak universities), as the expert estimate of the significance of the criteria might not be accurate. The advantage of applying to benchmark is that we can also identify the exact differences between the entities being compared, and also in which evaluation criteria the entity has the largest reserves and is the most remote from the global benchmark. The result of RQ3 implementation is the quantification of the correlation between the resulting scores of both benchmarking regions. We found this strong (85.5\%) dependence using the Pearson correlation coefficient and in 5 out of the 8 regions examined the resulting order was identical. Based on the correlation analysis, we have found a strong dependence between the start-ups 

Potential Indicators

implementation evaluation and the region's creative potential, which means that creativity and start-ups creation cannot be separated from each other, even if the individual assessment criteria differ (in case of evaluation of start-ups we put more emphasis on investment and in case of evaluation of the creative potential on culture). At the same time, we see a link with the region's overall standard of living - if the region is industrially advanced (start-ups, innovations), employment, incentives to do business and willingness to stay in the region increase, and household spending on non-core goods is also increasing (e.g. culture), thereby developing the creative industry.

The main contribution of the paper is in the accuracy of benchmarking, in its ability to clarify the position of the self-governing region within Slovakia and in the simple search for weaknesses of regions that can serve as development potential.

In theoretical sources, benchmarking is predominantly linked to comparing products, services, and processes to competition, and the competitiveness of regions is relatively unexplored, which we can also be seen as products from a marketing perspective by being distinguished by tourist attractiveness, living standards, cultural differences, working and learning opportunities as well as entrepreneurial and innovative attractiveness. All the above-mentioned facts may also affect the marketing communication of the territory, which must be effectively communicated to the relevant market segment (tourist, job or study seeker, entrepreneur). We want to continue to explore the creative and innovative potential of regions in the future.

Based on our relationship with open innovations and the incentives for research from «outside», we also asked students (future managers or entrepreneurs) open questions in the questionnaire (Appendix $\mathrm{B}$ ), and they had the opportunity to respond voluntarily and contribute to our visions with their ideas. We know that the region's creative and innovative potential can be measured not only by our criteria and by using creative indices, so respondents have also been allowed to identify other criteria by which to evaluate creative and innovative potential. Interesting answers include, for example, the degree of eco-innovation, corporate social responsibility, the use of creative methods and IT in teaching, and the percentage of schools in which entrepreneurship and financial literacy are taught. As far as career prospects of university students specializing in economics are concerned, most of them plan to be employed after graduation (tourism is the most attractive sector), but they do not exclude the establishment of their own business in the future.

From the regional point of view, most students are planning to settle (employ or do business) in Slovakia, but many do not exclude temporary work abroad (especially in Western Europe) to gain work experience, get to know other cultures, bring ideas and capital to start their own business in Slovakia or Ukraine in case of Ukrainian students. In particular, the lack of advice in this area, insufficient capital, insufficient support for science and research by the government and the EU, corruption and the influence of the socialist regime on the Slovak economy are considered the biggest barriers to innovative business and start-ups. Among the psychological qualities of the Slovaks, the respondents mentioned conservatism, unwillingness to try something new, fear of failure, negative perception of the entrepreneur in society, prejudices and lack of use of creative methods in schools of every type, resp. prevalence of memorization.

As management students at a Christian-oriented university were also among the respondents, we asked how this kind of education could affect the region's creative potential. The most frequent answers were motivation and belief in the entrepreneur's abilities, which are gifts from God, humanity and ethical behaviour of the entrepreneur to employees (fair wage, good working conditions, growth opportunities), respect for their opinions and ideas, perception of work as a mission, reduction of corruption, guiding innovation to be valuable to the individual and society (protecting the environment, protecting science and research from misuse, for example, genetic manipulation, cloning, weapons, etc.) and the willingness to admit a mistake not only in private life but also in business which is the basis for innovation, similar to Kosturiak (2010) in its publication. 
Author Contributions: Conceptualization, J.P. and M. V.; methodology, J. P.; software, M. V.; validation, J. P. and M. V., formal analysis, M. V.; investigation, J. P. and M. V.; resources, J. P. and M. V.; data curation, J. P.; writing-original draft preparation, J.P.; writing-review and editing, J.P. and M. V.; visualization, M. V.; supervision, J. P.; funding acquisition, J. P. and M. V.

\section{References}

Ali Taha, V., Tej, J. (2015). Tvorive metody v manazmente. Presov, Bookman.

Araya, D., Peters, M. A. (2010). Education in the Creative Economy: Knowledge and Learing in the Age of Innovation. New York, Peter Lang Publishing.

Bacik et al. (2019). Management of competitiveness and economic performance in the V4 countries.Marketing and management of innovations, 10 (3), 73-88.

Bartley, B. et al. (2007). Best practices in achieving a customer-focused culture. Benchmarking: An international journal, 14 (4), 482-496.

Blank, S. (2010). What's A Startup? First Principles, available at: https://steveblank.com/2010/01/25/whats-a-startup-firstprinciples (accessed 5 March 2019).

Borsekova, K. et al. (2015). Nostalgic sentiment and cultural and creative industries in regional development: A Slovak case study. Quaestiones geographicae, 34 (2), 53-63.

Crnogaj, K. et al. (2015). Supporting economic growth with innovation-oriented entrepreneurship. Ekonomicky casopis, 63 (4), 395-409.

Carnicky, S. et al. (2017) Productivity development and convergence Gross the EU member states. Economic annals XXI, 162 (11-12), 13-17.

Cichovsky, L., Bohacek, J., Urban, J. (2012). Moderni pojeti inovaci a jejich typologii pro praxi. Prague, Adart.

Dacey, J. S., Lennon, K. H. (1998). Understanding creativity: The interplay of biological, psychological and social factors. San Francisco, Jossey-Bass.

Denning, S. (2014). Identifying the new opportunities and threats in the creative economy. Strategy \& Leadership, 42 (6), 3-9.

Dhir, S. (2016). Practice-oriented insights on creative problem solving. Journal of Management \& Public Policy, 7 (2), 5-7.

Dibrova, A. (2017). Analysis of crowdfunding in European Union: Performance and perspectives. Contemporary issues in finance: Current challenges from across Europe, 98 (1), 37-48.

Ferasso, M. et al. (2018) Innovation ecosystems: a meta-synthesis. International journal of innovation science, 10 (4), $495-518$

Fila, M., Kucera, J. (2015). Sucasny stav inovacnej vykonnosti Slovenska a slovenskych MSP. Produktivita a inovacie, 16 (2), 25-30.

Fitrinitia, I. S. et al. (2018). Creative class for making a good city. IOP Conference Series: Earth and environmental science, proceedings of the international conference in Jakarta. Indonesia, Jakarta, Institute of Physics, article No. 012053.

Florida, R. (2002). The rise of the creative class. New York, Basic Books.

Florida, R., Tinagli, I. (2004). Europe in the creative age. London, Demos.

Frankova, E. (2011). Kreativita a inovace v organizaci. Prague, Grada Publishing.

Gunasekaran, A., White, D. S. (2009) Performance measures and benchmarking in business innovation. Benchmarking: An international journal, $16(3)$.

Havier, J., Vrtikova, K. (2016). Start-up ako moderna forma podnikania. Ekonomika, financie a manazment podniku: Zbornik vedeckych prac pri 75. vyroci zalozenia EU BA, Bratislava, EU BA.

Herve, F., Schwienbacher, A. (2018). Crowdfunding and innovation. Journal of economic surveys, 32 (1), 514-1530.

Howkins, J. (2002). The Creative Economy: How People Make Money from Ideas. London, Penguin Books.

Hudec, O., Klasova, S. (2016). Slovak creativity index - a PCA based research. European spatial research and policy, 23 (1), 47-64.

Ivanicka, K. et. al. (2014). Trvala udrzatelnost' inovacii v rozvoji Slovenska. Bratislava, Wolters Kluwer.

Janakova, H. (2015). The Success Prediction of the Technological Start-up Projects in Slovak Conditions. Procedia Economics and Finance, 34 (1), 73-80.

Kiselakova, D., Sofrankova, B. (2014). Moderny financny manazment podnikatelskych subjektov. Presov, Bookman.

Khanmirzaee, S. et al. (2018). A study on the role of science and technology parks in development of knowledge-based economy. World journal of entrepreneurship, management and sustainable development, 14 (1), 74-85.

Klempova, M. (2014). Startup: Univerzalna definicia neexistuje, available at: https $>/ /$ sweb.mtf.stuba.sk/monitoring/clanky/ 1396338446_strategie.pdf (accessed 28 February 2019).

Kloudova, J. (2009). Kreativni ekonomika a jej mereni. Ekonomicky casopis, 57 (3), 247-262.

Kloudova, J., Chwaszcz, O. (2014). The analysis of the creative industry linked in connection with the economic development. E\&M Economics and Management, 14 (1), 32-42. 
J. Pitekova, M. Vrablikova. Benchmarking of Slovak Regions in Terms of Start-UP Implementation Indicators and Creative Potential Indicators

Knoskova, L., Dudekova, A. (2015) Hodnotenie inovacnej vykonnosti SR v kontexte EU. Studia Commercialia Bratislavensia, 8 (3), 393-406.

Kosturiak, J. (2010). Uvahy na kazdy deň: Zamyslenia a otazky o manazmente, podnikani a zivote. Bratislava, Karmelitanske nakladatelstvo.

Kovalova, M., Nogova, Z. (2016). Creative approach to the innovations based on the product benchmarking results. Innovation management, entrepreneurship and corporate sustainability (IMECS 2016): proceedings of the international conference in Prague. Prague, VSE, 338-348.

KPMG: Startup Ecosystem Survey. 2016, available at: https://assets.kpmg/content/dam/kpmg/pdf/2016/06/startup-ecosystemsurvey-slovakia-2016.pdf (accessed 10 March 2019)

Lesakova, L. et al. (2017). Innovation Leaders, Modest Innovators and Non-innovative SMEs in Slovakia: Key Factors and Barriers of Innovation Activity. Organizacija, 50 (1), 325-358.

Marcolin, F., Vezzetti, E., Montagna, F. (2017). How to practise Open Innovation today: what, where, how and why. Creative Industries Joural, 10 (3), 258-291.

Mikulastik, M. (2010). Tvorivost a inovace v praci manazera. Prague, Grada Publishing.

Neulogy, a. s. (2013). Sprava o stave a potenciali kreativneho priemyslu na Slovensku. available at: www.culture.gov.sk/extdoc/5040/sprava-kreativny-priemysel_MKSR_Neulogy (accessed 12 March 2019).

Miranda, M. G., Borges, R. (2019). Technology - based business incubators: An exploratory analysis of intraorganizational social networks. Innovation \& Management Review, 16 (1), 36-54.

Omoregie, O. K. (2019). Improving corporate performance with benchmarking - Some contemporary insight. Arabian journal of business and management review, 8 (5), 1-8.

Opait, G, Damian, D., Capatina, A. (2019). Freelancer as an entrepreneur: a choice as career development. Marketing and management of innovations, 10 (3), 327-340.

Park, Y. W. et al. (2012). Benchmarking open and cluster innovation: case of Korea. Benchmarking: An international journal, $19(4-5), 517-531$

Purnomo, B. R., Kristiansen, S. (2018). Economic reasoning and creative industries progress. Creative Industries Journal, 11 (1), 3-21.

Regional Innovation Scoreboard (2017). available at: http://ec.europa.eu/growth/ industry/innovation/facts-figures/regional_en (accessed 12 March 2019).

Ritter, S. M., Mostert, N. M. (2018). How to facilitate a brainstorming session: The effect of idea generation techniques and of group brainstorm after individual brainstorm. Creative Industries Journal, 11(3), 263-277.

Schumpeter, J. A. (1912/2006). Theorie der wirtschaftlichen Entwicklung. Berlin, Drucker \& Humboldt.

Slavik, S. (2018). Insight into start-up, its action and surroundings. Economic Annals XXI. 170 (1), 32-37.

Slovak Startup Report 2016: Part of the V4 Start-up survey. (2016), available at: https://www.startitup.sk/wpcontent/uploads/2016/11/file-1478174997-581b2915dd7c5.pdf (accessed 10 March 2019)

Suwala, L. (2012). Kreativitat, Kultur und Raum: ein wirtschaftsgeographischer Beitrag am Beispiel des kulturellen Kreativitatsprozesses. Berlin, Humboldt Universitat.

Sofrankova, B., Kiselakova, D., Cabinova, V. (2017). Innovation as a source of country's global competitiveness growth." in Innovative Economic Symposium 2017 (IES 2017): Strategic partnership in international trade, proceedings of the international conference in Ceske Budejovice, Czech Republic, Ceske Budejovice, VSTE, 1-12.

Soltes, M., Stofa, T. (2016). Crowdfunding - The Case of Slovakia and the Czech Republic. Quality Innovation ProsperityKvalita Inovacia Prosperita, 20(1), 89-104.

The Global Competitiveness Report. (2018), available at: http://www3.weforum.org/docs/GCR2018/05FullReport/TheGlobal CompetitivenessReport2018.pdf (accessed 15 March 2019)

Throsby, D. (2001). Economics and Culture. London, Cambridge University Press.

UNCTAD. (2010). available at: http://unctad.org/en/Docs/ditctab20103_en.pdf (accessed 15 March 2019)

Tyukhtenko, N. et al. (2019). Innovative development of the regions: cooperation between enterprises and state institutions. Marketing and management of innovations, 10 (3), 354-365

Vesela, D., Klimova, K. (2014). Knowledge based economy vs. Creative economy. Procedia - Social and behavioral science, 141 (1), 413-417.

VIcek, R. (2010). Inovace v hospodarske praxi. Olomouc, Moravska vysoka skola.

Vogl, M. (2015). Vyvoj, charakteristika a financovanie start-upov. Podnikatelske modely a podnikateske strategie start-upov I.: recenzovany zbornik vedeckych prac. Bratislava: EU BA, 2015.

Vrablikova, M., Loucanova, E. (2017). Aplikacia benchmarkingu vo vybranom drevospracujucom podniku. Ekonomicke spectrum, 12. (3).

Websites of some crowdfunding platforms, available at: https://www.crowdberry.eul, https://www.startlab.sk/projekty/, https://www.startovac.czl, https://www.hithit.com/cs/home (accessed 31 March 2019).

Websites of some consulting organizations and co-workings, available at: http://coworkingy.sk/, https://podnikam.sk/podnikatelske-inkubatory-mozu-vam-pomoct-rozbehnut-biznis/ (accessed 31 March 2019). 
J. Pitekova, M. Vrablikova. Benchmarking of Slovak Regions in Terms of Start-UP Implementation Indicators and Creative Potential Indicators

White, D. S. et al. (2014). Performance measures and metrics for the creative economy. Benchmarking: An international journal, 21 (1), $46-61$.

Zelenakova, D. (2017). Najznamejsie slovenske a ceske crowdfundingve platformy: Prehlad a porovnanie. available at: https://www.podnikajte.sk/financie///3192/category/financie-na-podnikanie/article/slovenske-ceske-crowdfundingove-platformy. xhtml (accessed 20 March 2019).

Zimermanova, K. (2015), Rozhodovanie o sposobe financovania investicii: Rizikovy capital.

Яна Пітекова, Ph.D., доцент, Католицький університет в Ружомберку (Словаччина);

Марія Враблікова, Католицький університет в Ружомберку (Словаччина)

Бенчмаркінг словацьких регіонів: впровадження Start-UP та розвиток креативного потенціалу

Креативні регіони сприяють підвищенню рівня якості життя суспільства, інвестиційної привабливості регіону, запуску Start-UP, створенню нових робочих місць, а також зменшують міграцію вчених та залучають здобувачів отримувати освіту у регіональних закладах вищої освіти. Метою статті є порівняння індикаторів ефективності запуску Start-UP та креативного потенціалу у регіонах Словаччини на рівні NUTS 3, а також кількісне оцінювання їх взаємозв'язку. Бенчмаркінг 8 словацьких регіонів NUTS 3 засновано на порівняннях двох груп індикаторів, а саме: 6 індикаторів ефрективності впровадження Start-UP (частота запуску Start-UP, створення радикальних інновацій, зайнятість у швидко зростаючих компаніях, обізнаність про венчурний капітал, обізнаність та можливості краудфандингу, консультування щодо запуску Start-UP) та 6 індикаторів розвитку креативного потенціалу (відкритість та різноманітність, людський капітал, культурне середовище, технології, інституційне середовище та творчі результати). У якості вихідної бази для розрахунків використано дані офріційних звітів про модифрікований словацький креативний індекс, регіональне інноваційне табло, відкриття інноваційних інкубаторів, краудфандингових платформ та їх веб-сайти. Для визначення ступеня впливу кожного з обраних індикаторів здійснено кабінетне дослідження та метод парного порівняння даних 91 респондента (студенти словацьких закладів вищої освіти економічної спрямованості, словацькою чи українською національністю). Відповідно до результатів парного порівняння, можливість консультування має найбільшу силу впливу на індикатори ефективності запуску Start-UP, а творчі результати - на розвиток креативного потенціалу. Емпіричні результати дослідження підтвердили високу ступінь кореляції (85,5\%) між аналізованими індикаторами при порівнянні регіонів. Авторами наголошено, що теоретичне значення статті полягає у розширенні традиційної теорії бенчмаркінгу (продукти, послуги, процеси), а саме аналіз з точки зору просторового розуміння (регіону). Основний практичний внесок статті полягає у виявленні слабких сторін обраних регіонів Словаччини за допомогою бенчмаркінгу. Отримані емпіричні результати можуть бути використані при розроблені регіональних стратегій та впровадженні нових навчальних програм у закладах вищої освіти.

Ключові слова: бенчмаркінг, творчий потенціал, регіон, Словацька Республіка, стартап.

Manuscript received: 12.07.2019.

(C) The author(s) 2019. This article is published with open access at Sumy State University. 